\title{
A Theoretical Support for Cultural Influence on Implementation and Acceptance of Assessment Centres for Malaysia Public Sector
}

Mohd Hanafiah Ahmad ${ }^{1}$ \& Mohd Rashid Ab Hamid ${ }^{2}$

${ }^{1,2}$ Universiti Malaysia Pahang, Malaysia

\begin{tabular}{l}
\hline \hline ARTICLE INFO \\
\hline \hline Article history: \\
Received: April 21, 2019 \\
Revised: August 2, 2019 \\
Accepted: September 20, 2019 \\
\hline
\end{tabular}

Keywords:

Assessment Centres,

Organisational Justice,

National Culture

\begin{tabular}{l} 
Clonflict of Interest: \\
None \\
\hline
\end{tabular}

Funding:

None

\begin{abstract}
This paper aims to provide a theoretical support on how culture influence the implementation and acceptance of assessment centres (ACs) in Malaysia. This paper aims to contribute to this research gap by exploring the implementation and acceptance of ACs in Malaysia, as an example of an Eastern, and developing, country. In this context, to analyse how culture influence the design and implementation of ACs, the model of cultural fit is reviewed to explain how culture influences human resource practices and ACs practice. Findings from the literature review show that model of cultural fit can be used to explain how physical and socio-political may influence internal and organisational work culture and, therefore, human resource practices. On the other hand, to understand the influence of culture on acceptance of ACs, organisational justice theory and employee engagement theory are reviewed and used to explain how candidates react to selection process. Findings from literatures search shows that culture may have influence on how ACs participant perceived fairness of the process by which outcomes are reached, or decisions are made.
\end{abstract}

Corresponding Author: Mohd Hanafiah bin Ahmad, Email: hanafiah@,ump.edu.my (C) Mohd Hanafiah Ahmad1 \& Mohd Rashid Ab Hamid

This is an open access article under the CC BY-SA 4.0 international license.

\section{Introduction}

Since the last five decades, Assessment centre (AC) has been a popular technique used in human resource management (Cahoon, Bowler, \& Bowler, 2012; Mueller-Hanson, Thornton, \& Rupp, 2017; Thornton, 2011) The core of this method is multiple work simulations activities which will help an organisation to obtain a large amount of information about a person in a relatively short period of time to support human resource decisions (Bray, 1982; Gibbons \& Rupp, 2009; Mueller-Hanson et al., 2017) Nowadays, this approach is widely used by organisations in various countries (Lanik \& Gibbons, 2011; Lievens \& Thornton, 2005). This is due to its adaptability to the different purposes of the AC, as well as to cultural, societal, and organisational requirements (Thornton, 2011). In Malaysia context, AC approach was used for the first time as part of the process for selection of Administrative and Diplomatic Officers in 1998 as part of the effort by the government to reform human resource practice in the public sector. However, although ACs play an important role in reforming HR practice in the Malaysian public sector, it is not clear how adaptation has been used to ensure that the ACs suit the local culture and other requirements. The literature search suggests that not much information was found on how the Malaysian government adopts ACs, or how local cultural values influence their design, implementation and acceptance.

As a result, there is a big gap in knowledge on how adaptations are made by the Malaysian Government in designing and implementing ACs practice as according to local context and Malaysian cultural settings, and how these local context and culture influence the acceptance of ACs. Therefore, it is the aim of this paper to fill in the blanks and to contribute to a better understanding of the issues associated with ACs practice in Malaysian public sectors by proposing a theoretical framework in evaluating how Malaysian Culture may 
influence the design and acceptance of ACs using model of cultural fit, organizational justice theory and employee engagement theory.

\subsection{Problem Statement}

Several scholars commented that most of the study on design, implementation and acceptance of ACs are mostly based on research conducted in societies in Western cultures (Claus \& Briscoe, 2009; Howard, 1997; Lanik \& Gibbons, 2011; Lievens \& Thornton, 2005; Thornton \& Povah, 2011). Therefore more research are required to study on how adaptations are made by the users. This is in-line with the suggestion from various studies in cross-cultural research which explained that management perceptions and approaches differ across cultures (Adler \& Aycan, 2018; Hampden-Turner \& Trompenaars, 2002). It has also been suggested that the adoption of any practices in management need to be suited to the particular organisations and/or countries in which those organisations operate (Adler \& Aycan, 2018; Adler \& Gundersen, 2008; Aycan et al., 2000; Mendonca \& Kanungo, 1996). Western assumptions of models and theories are not universally applicable and might not be appropriate in other parts of the world due to different cultures having different assumptions about social interactions, economic interests, legal requirements, and political realities. These contextual factors may also have an impact on human resource practices and strategies (Aycan, 2005; Gerhart \& Fang, 2005; Ryan et al., 2009; Wiechmann, Ryan, \& Hemingway, 2003). Yet, little is known about the adaptation of the wellestablished principles and techniques of western ACs to very different cultural and organisational contexts.

In addition, Ugwu and Ojeaga (2016) explain that employee acceptance and engagement is an emerging issue of 21 st century and is one of critical success factor for any organisations. In this context, a good staff selection process might give positive perception of justice and can affect organisational outcomes such as commitment, job satisfaction, withdrawal behaviour, citizenship behaviour and the organisational trust of employees (Zhang, LePine, Buckman, \& Wei, 2014). When candidates are treated fairly during the selection process, they feel need of reciprocal response to the organization in positive behaviour. The important of organisational justice is in-line with suggestion by scholars who explains that organisational justice is one of the most important internal leading factors affecting the employee engagement in the context of performance, emotion and behaviour (Scott, Garza, Conlon, \& Kim, 2014; Zhang et al., 2014). However, it is reported that lots of organisations are still struggling to improve employee engagement. In Malaysia, low engagement level remains as main issue for both private and public organisations. Report by Gallup (2013) shows that only $11 \%$ of employees are engaged, $81 \%$ are disengaged and another $8 \%$ is actively disengaged. In addition, a study by Kelly Global Workforce index report Malaysia scored below the global average for employee engagement, with only 28 per cent of Malaysian workers surveyed saying they are totally committed to their current employer (Awani, 2016).

Data from Public Service Commission of Malaysia as Table 1 shows that a drastic increasing number of candidates called to attend ACs from 2011 (8,258 candidates) to 42,288 candidates in 2013 (Public Service Commission of Malaysia, 2012, 2013, 2014). This may give an indication the important of AC approach in evaluating candidates to be a government officer.

Table 1: Statistics of Assessment Centre Activities for 2011, 2012 and 2013

\begin{tabular}{|c|c|c|c|c|}
\hline Year & $\begin{array}{l}\text { Number of } \\
\text { Assessment } \\
\text { Centre }\end{array}$ & $\begin{array}{l}\text { Number of Candidates } \\
\text { Called for Assessment } \\
\text { Centre Evaluation }\end{array}$ & $\begin{array}{l}\text { Number of Candidates } \\
\text { Attended Assessment } \\
\text { Centre Evaluation }\end{array}$ & $\begin{array}{l}\text { Number of Candidates } \\
\text { Passed Assessment } \\
\text { Centre Evaluation }\end{array}$ \\
\hline 2011 & 8 & 8,258 & 5,258 & 2,208 \\
\hline 2012 & 16 & 13,131 & 9,877 & 5,788 \\
\hline 2013 & 14 & 42,288 & 21,580 & 4,661 \\
\hline
\end{tabular}

Given the fact that the number of candidates attending these ACs is big and running ACs is costly in term of time and money (Thornton \& Gibbons, 2009), it is therefore important to ensure the design and implementation of these ACs is valid and suitable with Malaysian local context and culture. Since Hamid's recommendation in 1993 and its implementation in 1998, little is known on how the Malaysian government adopts ACs, or how local cultural values influence their design, implementation and acceptance. A number of scholars commented that the study on design, implementation and acceptance of ACs are mostly based on research conducted in societies in Western cultures (Claus \& Briscoe, 2009; Howard, 1997; Lanik \& Gibbons, 2011; Lievens \& Thornton, 2005; Thornton \& Povah, 2011). Therefore, more research is required to study on how adaptations are made by the users.

\section{Literature Review}




\subsection{Background of Assessment Centres}

Scholars suggest that the development of ACs began during the pre-World War II period, when the German military utilised a sophisticated multiple assessment procedure and multiple observers in order to evaluate complex behaviours for officer selection (Thornton \& Byham, 1982). Later, this approach was adapted by the British government for the selection of military officers (Moses \& Byham, 1977). In 1942, The Office of Strategic Services (OSS) then used this approach for selection and placement in the United States (MacKinnon, 1977). The main aim of the OSS programme was to assess the personality traits and behavioural skills deemed necessary in candidates for positions such as intelligence agents, saboteurs and propaganda experts. This assessment was carried out through the application of various situational and performance exercises, including interviews, simulations and role plays (Bray, 1982; MacKinnon, 1977; OSS Assessment Staff, 1948; Thornton \& Byham, 1982). In non-military settings, the British Civil Service Commission was the first organisation to apply the AC concept, in 1945 (Moses \& Byham, 1977; Thornton \& Byham, 1982). Later, in 1956, the AC approach was introduced into the industrial sector by the American Telephone and Telegraph Company (AT\&T).

The design of AC involves multiple assessment processes, where a group of participants takes part in exercises and is observed by a team of trained assessors who evaluate each participant against a number of predetermined, job-related behaviours (Lanik \& Gibbons, 2011; Mueller-Hanson et al., 2017; Rupp et al., 2015; Thornton \& Rupp, 2006; Thornton, Rupp, \& Hoffman, 2014). Participants in an AC are measured and rated by trained assessors on job-related dimensions which is designed to replicate on-the-job situations (Gatewood \& Feild, 2008; Lanik \& Gibbons, 2011). The most commonly simulation exercises used are case analyses, in-baskets, oral presentations, role-plays and group discussions (Bowler, Woehr, Soc, \& Org, 2006; Dilchert \& Ones, 2009; Lievens, Chasteen, Day, \& Christiansen, 2006). Results from all the simulation exercises are pooled in a discussion-based meeting among assessors, by a statistical integration process, or a combination of both approaches (Rupp et al., 2015; Thornton \& Gibbons, 2009). Scholars suggested that ACs may be able to help an organisation obtain a large amount of information about a person in a relatively short period of time which useful to facilitate decisions for selection or promotion purposes, to diagnose training needs, or to facilitate employee development (Ballantyne \& Povah, 2004; Cahoon et al., 2012; Rupp et al., 2015; Thornton \& Rupp, 2006). As a result, this approach is now widely used by organisations in many countries, not only for managerial positions but also for non-managerial positions at different levels (Lanik \& Gibbons, 2011).

\subsection{Assessment Centres in Malaysia}

The suggestion of using an ACs approach was first proposed by Hamid, the Chief Secretary of the Government of Malaysia (Hamid, 1993) as part of the effort by the government to reform human resource practice in the public sector. Hamid (1993) suggested that ACs should be used to improve the process of selecting suitable candidates to work in the government sector. AC approach was then used for the first time as part of the process for selection of Administrative and Diplomatic Officers in 1998. The government judged the approach to be a success in improving transparency in the selection process and helping measure candidates' competencies and abilities, and the use of ACs was extended for selection purposes to three other positions in 2009 (Public Service Commission of Malaysia, 2011). Later in 2011, Public Service Commission of Malaysia has introduced profiling recruitment model or MyRecruitment to get the best-suited candidates in terms of personality, interests, attitude, skills and knowledge (Public Service Commission of Malaysia, 2011). As shown in Figure $1, \mathrm{AC}$ is used as part of this new profiling recruitment model.

\subsection{Assessment Centres in Malaysia}

The suggestion of using an ACs approach was first proposed by Hamid, the Chief Secretary of the Government of Malaysia (Hamid, 1993) as part of the effort by the government to reform human resource practice in the public sector. Hamid (1993) suggested that ACs should be used to improve the process of selecting suitable candidates to work in the government sector. AC approach was then used for the first time as part of the process for selection of Administrative and Diplomatic Officers in 1998. The government judged the approach to be a success in improving transparency in the selection process and helping measure candidates' competencies and abilities, and the use of ACs was extended for selection purposes to three other positions in 2009 (Public Service Commission of Malaysia, 2011). Later in 2011, Public Service Commission of Malaysia has introduced profiling recruitment model or MyRecruitment to get the best-suited candidates in terms of personality, interests, attitude, skills and knowledge (Public Service Commission of Malaysia, 2011). As shown in Figure $1, \mathrm{AC}$ is used as part of this new profiling recruitment model. 


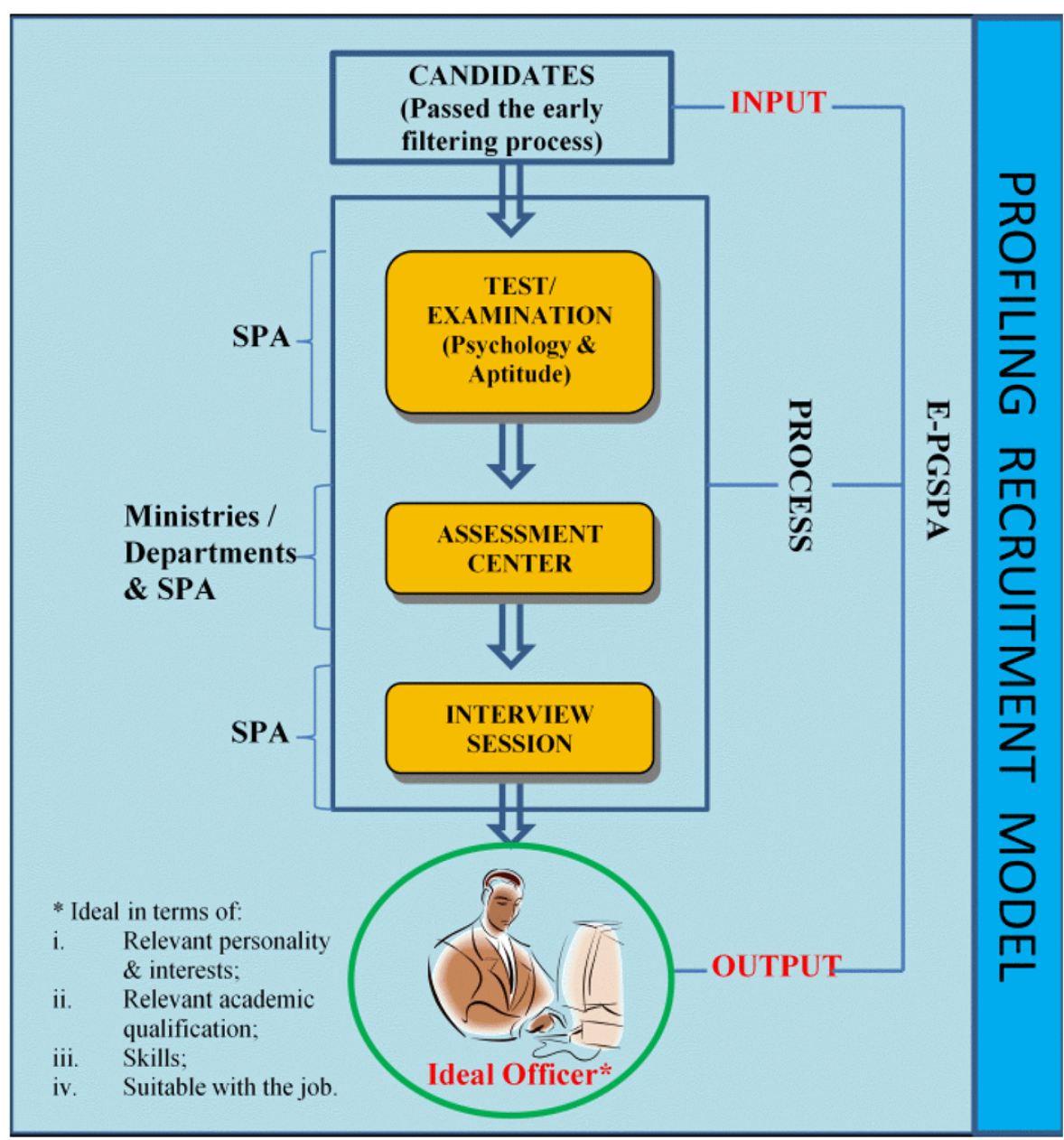

Figure 1: Profiling Recruitment Model

\subsection{Review on Malaysian Culture}

Review on literatures shows that culture has been defined using different approaches and conceptualised in various research areas, but without agreement on a single concept or meaning (Lustig \& Koester, 2003). It is however shows that the concept of culture conceptions are normally express in statements of specific people's beliefs, values and thinking; which reflect into their behaviour, as well as their ways in acting and living (Hofstede, 1991, 2001; Schein, 2004). In the context of Malaysian culture, it is found that Malaysian is a society that is strong power distance and hierarchies, collectivism and relationship preferences, and prefer to use high context communication (Abdullah \& Low, 2001; Bakar, 2017; Hofstede \& Hofstede, 2004; House et al., 1999)

\section{Power Distance and Preference of Hierarchy}

Studies by Western scholars like Hofstede (Hofstede, 1980, 2001) and the GLOBE research by House et al. (House et al., 1999; House, Hanges, Javidan, Dorfman, \& Gupta, 2004), showed Malaysia is a society that scores highly on power distance. Employees in high power distance society tend to create a formal relationship within their organisations, with high reliance on supervision to ensure effective implementation of the given tasks. In this regard, members of such a society or organisation tend to expect, and agree, that power should not be equally shared (Hofstede, 1980; House et al., 1999, 2004). Organisations normally practice a hierarchical organisational structure with many supervisory personnel, wherein subordinates are expected to be informed as to their tasks (Hofstede \& Hofstede, 2004). There is also a tendency to authoritative leadership styles in high power distance societies and organisations (Rosner \& Kleiner, 1998). Studies by Malaysian researchers support the finding that Malaysia is a high power distance society and tends to place emphasis on respect to elders, authority and hierarchical differences (Abdullah \& Lim, 2001; Abdullah \& Pedersen, 2003; Bakar, 2017; Lim, 2001).

Collectivism and Relationship Preferences 
Studies also found that Malaysian society is more group- than individual-oriented. This is in line with the findings of various studies that indicate that Malaysia is a collectivist society (Blunt, 1988; Hofstede, 1980; House et al., 1999). This is also supported by local Malaysian research, for example Abdullah (1992) who found that Malaysians work much better in a group, as they have a strong sense of belonging. The spirit of teamwork is important, which can be seen by the readiness to put group interests ahead of individual concerns. Abdullah (1992) explains that satisfaction at work comes from having opportunities to receive appropriate respect from fellow colleagues and maintaining harmonious, predictable and enjoyable friendships with subordinates and peers.

\section{High Context Communication}

A third important finding in regards to Malaysian culture is in the context of communication (Abdullah \& Pedersen, 2003; Z. Abdullah, 2010; Abu Bakar, Bahtiar, \& Mustafa, 2007; Amir, 2009; Bakar, 2017; Salleh, 2005). Hall (1976) and Rogers, Hart, and Miike (2002) explain that high context-cultures like Asians prefer to use high-context communication. This cultural context assumes that most information resides in the person and therefore it is important to understand informal and body language in communication. A study by Salleh (2005) shows that Malaysian put higher emphasis in high communication context as part of the process of maintaining harmony, to avoid confrontation, criticism and outspokenness, as it may damage self-esteem or standing.

\subsection{Theoretical Model}

\subsubsection{Model of Cultural Fit}

The model of cultural fit (MCF), is used to explore how culture influence the design and implementation of ACs. This model was proposed by Mendonca and Kanungo (1994) to study how physical and socio-political may influence internal and organisational work culture and, therefore, HRM practices. The important feature of a MCF is that it maintains a distinction between cultural dimensions at the societal and organisational levels. This model asserts that socio-cultural variables (e.g. individualism/collectivism, power distance, etc.) may influence an organisation's internal work culture, which, in turn, influences HRM practices and thus AC design and implementation.

The organisation's internal work culture in this model consists of managerial beliefs and assumptions regarding two essential elements of the organisation, which are the task and the employees (Schein, 1992, 2004). Managerial assumptions regarding the task deal with the nature of the task and how it can be best accomplished. This task-driven assumption is influenced by an organisation's characteristics, which include resource availability, whether it is a private or public sector, the industry in which it operates and its market competitiveness.

The employee-related assumption deals with the nature and behaviour of employees, which is influenced by the socio-cultural environment. As a result, these managerial assumptions about the nature of the task and the employee will influence managers in their design and implementation of human resource practices (Aycan, 2005; Aycan et al., 2000; Keles \& Aycan, 2011). Figure 2 bellows summarise the model of cultural fit

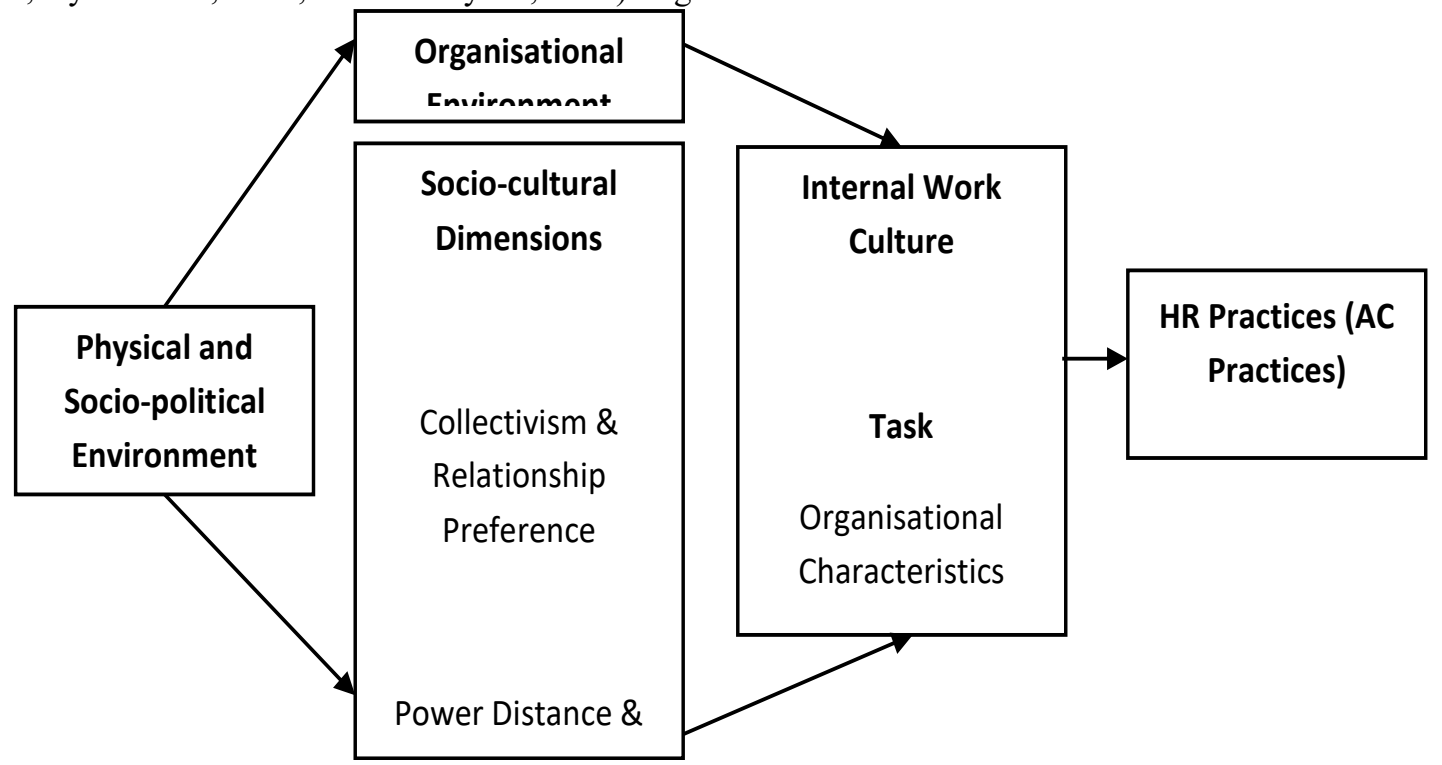

Figure 2: The model of cultural fit (adapted from Aycan, 2005; Aycan et al., 1999; Aycan et al., 2000; Keles \& Aycan, 2011) 


\subsubsection{Model of Organisational Justice}

To explore the acceptance of AC practices in Malaysia, this study adapted the organisational justice model. Organisational justice is concerned with what people think is fair and how they react if they believe that the procedures to make the decision, or distribute the resources, are unfair (McCarthy et al., 2017; Steiner \& Gilliland, 2001) This model consists of two sub elements, i.e. distributive and procedural justice (Bies \& Tripp, 1995; Steiner \& Gilliland, 2001). Procedural justice refers to the perceived fairness of the process by which outcomes are reached, or decisions are made (Garbers, Böge, Erdogan, \& Bauer, 2016; Lind, Tyler, \& Huo, 1997). The procedural justice consists of ten rules that can be categorised under three categories. The first category is structural aspect or formal characteristics, which include job-relatedness, chance to perform, reconsideration opportunity and consistency. Information sharing is the second category and it consists of feedback, information known and openness. The final category is interpersonal treatment, which includes treatment at the test site, two-way communication and the propriety of questions. Meanwhile distributive justice refers to how the outcome is distributed. Distributive justice is also closely related to equity and equality theory. Equity theory focuses on meritocratic in which the most highly performing candidates during the $\mathrm{AC}$ programme are the ones most likely to be hired. Meanwhile equality theory refers to the situation where outcomes are equally distributed among all individuals, which means that the evaluation is less based on individual merit. Equity is preferred if emphasis is given on productivity whereas equality in distribution is more important for group harmony.

\subsection{Cultural Implication on Assessment Centres Practice and Acceptance}

The development of an AC starts with a job analysis, which is required in order to identify those dimensions that are most important for the particular job under examination (Gatewood \& Feild, 2008). Various job analysis techniques may be used, including gathering information from subject matter experts, collecting data via questionnaires and interviews with supervisors and job incumbents. This suggestion concurs with Thornton and Rupp (2006), who stated that the use of a single method is not sufficient in conducting a thorough job analysis. It is however, culture may have an influence over the selection of methodology for the job analysis. For example, it has been found that the use of a traditional job analysis questionnaire to gather information from individual workers in high power distance cultures was problematic, as the jobs were designed to be performed by groups of workers, and not by individuals (Love, Bishop, Heinisch, \& Montei, 1994; Sanchez \& Levine, 1999). Malaysian as a high power distance society may see that it is not appropriate for subordinates to express individual opinions that may override superiors. As a result, employees seldom offer personal views to management. There is a tendency for employees to let management make decisions on issues related to them, including what they must do and how it should be done (Abdullah \& Pedersen, 2003; Aycan, 2005). Therefore, in this context, individual interview for job analysis might not suitable for development of Malaysian ACs.

In terms of simulation exercises, researchers have suggested that it is vital to identify which exercises are relevant for the criterion domain that one tries to predict in a specific culture. For instance, it has been suggested that leaderless group discussions, role-plays and individual presentations are less likely to be effective in high power distance cultures (Aycan, 2005; Lievens \& Chapman, 2009). In this regards, Lievens, Harris, van Keer, Bisqueret and Acad (2003) found that Japanese supervisors rated a group discussion exercise as a more powerful predictor of future performance than individual presentations. This explain that Japanese supervisors prefer group-based exercises as it reflects their collectivist culture, which favours team-based decision making. A study by Earley (1994) also found similar results. His findings showed that group-focused training was more effective at improving self-efficiency and performance among collectivist (Chinese) participants. For individualist (American) participants, however, individual-focused training was more effective. In this context, it is important for Malaysian ACs to design simulation exercises that are more team-based activities as compared to individual activities. Likewise, the empirical findings of Bernthal and Lanik (2008, as cited in Lanik \& Gibbons, 2011) showed that, during the interaction role-plays activities, as compared to participants from European countries and North America, participants from Asian countries were more focused on relationship building and less on the task that needed to be accomplished. In this regard, scholars have explained that, in collectivist societies, building relationships is considered to be an important step in accomplishing the task (Abdullah \& Pedersen, 2003; Lanik \& Gibbons, 2011).

Therefore, those who have skill in building relationships might have an advantage during these activities. Lanik and Gibbons (2011) explained, however, that for Western assessors, this relationship-building behaviour might be viewed as irrelevant to the exercise and they might pay little attention to it. This situation may reflects the assessment criteria for ACs in Malaysia which should not focus only on final result but also the proses during the activities including relationship building. In the context of interpersonal treatment, Malaysian as a society that put emphasis on working in group and maintaining harmony, good interpersonal relationship is important in helping the group to perform better. As mentioned by Steiner and Gilliland (2001), commented that opportunities to perform and job relatedness are factors related to individualism whereas consistency of 
treatment and equality is more important in collectivist societies. Although work outcomes are important in collectivist cultures, social and relationship criteria are given more emphasis in evaluating performance. Performance dimensions in collectivistic cultures are focused more on work processes (e.g., effort, motivation, etc.) and interpersonal competencies (e.g., respect, positive attitude towards superiors, etc.). To support this suggestion, Aycan (2005) explained that recruitment and selection process as well as performance evaluation in high power distance and collectivist culture are more towards 'soft criteria' (e.g. social and interpersonal skills, etc.).

It is common that most of the exercises in an $\mathrm{AC}$ are verbal in nature (e.g., group discussions). In this context, in order to evaluate candidates' competencies in these kinds of activities, they are required to speak up and express their ideas (Lanik \& Gibbons, 2011). It has been found, however, that culture has a strong influence on the appropriateness of speaking and expressing an opinion aloud (Abdullah \& Pedersen, 2003; Imada, Van Slyke, \& Hendrick, 1985; Pendit, 2011). If the assessors fail to understand this situation, their judgement of a candidate's behaviour might be inaccurate (Lanik \& Gibbons, 2011). For instance, Pendit (2011) explained that it is not easy for Indonesians to express their opinions directly (high context communication). They usually take a longer time and the words they use are often filled with hidden meaning and metaphors in comparison to Western participants. In the same vein, it has also been noted that the Filipino culture encourages deferring to others in group settings, which might mean that they speak very little in a leaderless group discussion exercise (Imada et al., 1985). Therefore, it is vital for the assessors to be trained and understand this high communication context among participants in completing the simulation activities.

In the context of training design for the assessors, it is important to consider cross-cultural variations in cognitive learning styles (Savvas, El-Kot, \& Sadler-Smith, 2001). For instance, Allinson and Hayes (2000) found that managers in developing countries were more analytical, which means that they were typically seeking certainty. In contrast, they found that managers in more developed countries were more intuitive, meaning that they are more likely to argue against norms and assumptions than managers in less developed countries, thereby undermining the power distance between the trainer and the trainee. Aycan (2005) explained that analytical thinkers in high power distance and high uncertainty cultures are more receptive to one-way lecture-style training than they are to participative discussion. In order to conduct training in this type of culture, instructors must, therefore, be able to give definitive answers (Thornhill, 1993). Therefore, in designing ACs training to the assessors, it is preferable to have high-level managers in high power distance and high uncertainty cultures as the instructors, rather than hiring external consultants, or trainers (Wright, Szeto, \& Cheng, 2002).

Scholars also suggest that there is a tendency of reluctant to seek or share feedback and information in high power distance society. An appeal of process is not common in this culture because it is considered as challenging authority (Fletcher \& Perry, 2001). Similarly, Steiner and Gilliland (2001) explain that power distance is an important influence on information sharing. Therefore, cultural differences may also influence the communication methods used to give feedback and information sharing. Fletcher and Perry (2001) described the process of giving feedback in collectivistic cultures as indirect, private and non-confrontational. They found that it is not common for employees in high power distance cultures to make an appeal on their performance feedback, as this may be considered to be challenging authority. As collectivist cultures emphasize harmony in the workplace, there is also a tendency to avoid giving negative feedback. For example, some organisations in the Philippines provide different reports for performance feedback, where the report given to the employee is phrased more positively than that presented to the HR department (Aycan, 2005; Vallance \& Fellow, 1999). Aycan (2005) also explained that there is a reluctance to seek feedback in collectivistic and high power distance cultures. Furthermore, in collectivist cultures, positive feedback on individual performance is not well received, as it may cause envy among others who did not receive such positive feedback (Aycan, 2005). A comparative study among US, Japanese and Chinese employees supports this argument (Bailey, Chen, \& Dou, 1997). These researchers found that Japanese and Chinese employees preferred not to seek feedback on individual performance, but preferred to seek feedback on group performance. In this context, Malaysian ACs need to design a suitable ways in delivering the feedback which should be in group and in the same time able to maintain harmony among the participants.

In the context of distributive justice, it is commonly measured from the perspective of equity, equality, or needs (Steiner \& Gilliland, 2001). In the context of ACs, equity refers to the meritocratic situation where the most highly performing candidates during the AC programme are the ones most likely to be hired. Meanwhile, equality is a perspective in which outcomes are equally distributed among all individuals, which means that the evaluation is less based on individual merit (Steiner \& Gilliland, 2001). In general, Kabanoff (1991) explained that equity is preferred if emphasis is given on productivity whereas if the focus is more on group harmony, equality in distribution becomes more important. In the context of personnel selection processes, Steiner and Gilliland (2001) explained that most methods used are based on the equity principle, with a candidate's competencies evaluated against a number of predetermined, job-related behaviours (Krause \& Thornton, 2006; Lanik \& Gibbons, 2011). Steiner and Gilliland (2001) commented, however, that the use of 
the equity method is more likely to occur in an individualistic society. In contrast, as harmony is given more priority in a collectivistic society, such cultures are more likely to prefer equality approaches (James, 1993). However, Malaysia as a collectivist society which put emphasis on maintain harmony, reward is normally given to the group and not to an individual person. Therefore for Malaysian ACs, equality should be used in distributing the outcome of the assessment.

\subsection{Proposed Theoretical Framework}

This paper focuses on exploring the influence of culture on the design of Malaysian ACs practice and its acceptance. Based on discussion above, the diagram in Figure 3 below is a proposed theoretical framework to understand how culture influence the design and participants' reactions to ACs practice. In this regards, from a theoretical perspective, there are two main areas related to this study. One is model of cultural fits; the other is organisational justice.

The former refers to the perceived fairness of the process by which outcomes are reached, or decisions are made. Understanding how local cultures influence the design as well as and reactions to the design of ACs and the outcome is important to ensure that the operation of these systems is fair, smooth and effective to the local context.

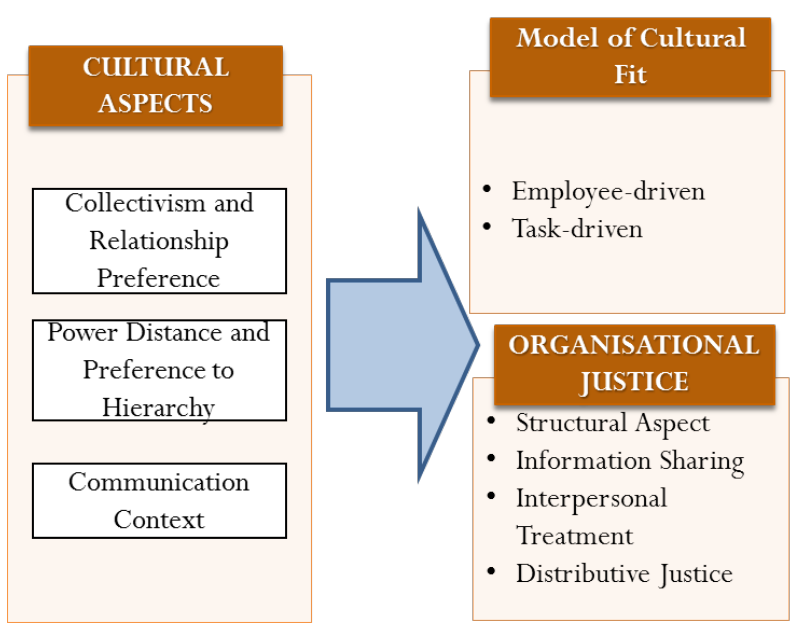

\section{ACs DESIGN}

\begin{tabular}{|ll|}
\hline 1. & Job analysis (behaviours) \\
2. & Behavioural classification (dimensions) \\
3. Links: behaviours $>$ dimensions $>$ exercises \\
4. Multiple assessments \\
5. Simulations \\
6. Multiple assessors \\
7. Assessor training \\
8. Recording behaviour (e.g., in writing, \\
videotape) \\
9. Reports (e.g., summary of strengths and \\
weaknesses) \\
10. Data integration
\end{tabular}

Figure 3: Conceptual Frameworks for Acceptance of Assessment Centres

\section{Conclusion}

The aim of this paper is to propose a theoretical framework that can be further developed and tested by future empirical studies. The theoretical framework describes theoretical support on cultural influence on implementation and acceptance of ACs in Malaysia by using the model of cultural fit and organisational justice theory. Based on literature search, the possible relationships between these two elements are discussed. The workability of this research framework has to be explored and tested using empirical data in the context of ACs practice in Malaysia.

\section{References}

Abdullah, A. (1992). The influence of ethnic values on managerial practices in Malaysia. Malaysian Management Review, 27(1), 3-18.

Abdullah, A., \& Lim, L. (2001). Cultural dimensions of Anglos, Australians, and Malaysians. Malaysian Management Review, 36(2), 1-17.

Abdullah, A., \& Low, A. H. M. (2001). Understanding the Malaysian workforce: guidelines for managers. Kuala Lumpur: Malaysian Institute of Management.

Abdullah, A., \& Pedersen, P. (2003). Understanding multicultural Malaysia: Delights, puzzles \& irritations. Petaling Jaya: Pearson/Prentice Hall.

Abdullah, Z. (2010). Cultural diversity management in Malaysia: A perspective of communication management. In M. Özbilgin \& J. Syed (Eds.), Managing cultural diversity in Asia (pp. 14-38). Gheltenham: Edward Elgar Publishing Limited.

Abu Bakar, H., Bahtiar, M., \& Mustafa, C. S. (2007). Superior-subordinate communication dimensions and working relationship: Gender preferences in a Malaysian organization. Journal of Intercultural Communication Research, 36(1), 51-69. 
Adler, N. J., \& Aycan, Z. (2018). Cross-Cultural Interaction: What We Know and What We Need to Know. Annual Review of Organizational Psychology and Organizational Behavior, 5(1).

Adler, N. J., \& Gundersen, A. (2008). International dimensions of organizational behavior (5th ed.). Mason, Ohio: Thomson South-Western.

Allinson, C. W., \& Hayes, J. (2000). Cross-national differences in cognitive style: implications for management. International Journal of Human Resource Management, 11, 161-170.

Amir, S. (2009). The influence of national culture on communication practices: A case study on Malaysian organisaton.

Awani, A. (2016). Malaysia below global average in employee engagement. Retrieved August 31, 2017, from http://english.astroawani.com/business-videos/malaysia-below-global-average-employeeengagement-32375

Aycan, Z. (2005). The interplay between cultural and institutional/structural contingencies in human resource management practices. International Journal of Human Resource Management, 16, 1083-1119.

Aycan, Z., Kanungo, R. N., Mendonca, M., Yu, K. C., Deller, J., Stahl, G., \& Kurshid, A. (2000). Impact of culture on human resource management practices: A 10-country comparison. Applied Psychology An International Review, 49, 192-221.

Aycan, Z., Kanungo, R. N., \& Sinha, J. B. P. (1999). Organizational culture and human resource management practices: The model of culture fit. Journal of Cross-Cultural Psychology, 30, 501-526.

Bailey, J. R., Chen, C. C., \& Dou, S. G. (1997). Conceptions of self and performance-related feedback in the US, Japan and China. Journal of International Business Studies, 28, 605-625.

Bakar, H. A. (2017). Explaining Cohesion Linkages in Workgroups: The Cooperative Communication in Collectivism and High Power Distance Workgroup Context. Jurnal Komunikasi, Malaysian Journal of Communication, 33(3).

Ballantyne, I., \& Povah, N. (2004). Assessment and Development Centres (2nd.). England: Gower.

Bies, R. J., \& Tripp, T. M. (1995). The use and abuse of power: Justice as social control. In R. Cropanzano \& K. Kacmar (Eds.), Organizational politics, justice, and support: Managing social climate at work (pp. 131-145). New York: Quorum Books.

Blunt, P. (1988). Cultural Consequences for Organization Change in Southeast Asian State: Brunei. Academy of Management Executive (08963789), 2(3), 235-240.

Bowler, M. C., Woehr, D. J., Soc, I., \& Org, P. (2006). A meta-analytic evaluation of the impact of dimension and exercise factors on assessment center ratings. Journal of Applied Psychology, 5, 1114-1124.

Bray, D. W. (1982). The assessment center and the study of lives. American Psychologist, 37, 180-189.

Briscoe, D. R. (1997). Assessment centers: Cross-cultural and cross-national issues. Journal of Social Behavior \& Personality, 12, 261-270.

Cahoon, M. V, Bowler, M. C., \& Bowler, J. L. (2012). A reevaluation of assessment center construct-related validity. International Journal of Business and Management, 7(9), p3.

Claus, L., \& Briscoe, D. (2009). Employee performance management across borders: A review of relevant academic literature. International Journal of Management Reviews, 11, 175-196.

Dilchert, S., \& Ones, D. S. (2009). Assessment Center Dimensions: Individual differences correlates and metaanalytic incremental validity. International Journal of Selection and Assessment, 17(3), 254-270.

Earley, P. C. (1994). Self or group? Cultural effects of training on self-efficacy and performance. Administrative Science Quarterly, 39, 89-117.

Fletcher, C., \& Perry, E. L. (2001). Performance appraisal and feedback: A consideration of national culture and a review of contemporary research and future trends. In N. Anderson, O. D.S., \& V. C. (Eds.), Handbook of Industrial, Work and Organizational Psychology (Vol. 1, pp. 127-146). London: Sage.

Gallup Poll. (2013). State of the global workplace: Employment engagement insights for business leaders worldwide. Washington, D.C.

Garbers, Y., Böge, M., Erdogan, B., \& Bauer, T. N. (2016). Antecedents and Consequences of Procedural Fairness Perceptions in Personnel Selection: A Three-Year Longitudinal Study. Group \& Organization Management.

Gatewood, R. D., \& Feild, H. S. (2008). Human resource selection. Mason, Ohio: Thomson/South-Western.

Gerhart, B., \& Fang, M. Y. (2005). National culture and human resource management: assumptions and evidence. International Journal of Human Resource Management, 16(6), 971-986.

Gibbons, A. M., \& Rupp, D. E. (2009). Dimension consistency as an individual difference: A new (old) perspective on the assessment center construct validity debate. Journal of Management, 35(5), 1154-1180.

Hall, E. T. (1976). Beyond Culture. New York: Anchor Press / Doubleday.

Hamid, A. S. A. (1993). Closing ceremony speech by the Chief Secretary of the Government of Malaysia. In Persidangan ketiga suruhanjaya-suruhanjaya perkhidmatan awam Malaysia dan negeri-negeri. Kangar, Perlis, Malaysia. 
Hampden-Turner, C., \& Trompenaars, F. (2002). A mirror-image world: Doing business in Asia. In Malcolm Warner \& Pat Joynt (Eds.), Managing Across Culture, Issues and Perspective (2nd ed.). London: International Thomson Business Press.

Hofstede, G. (1980). Culture's consequences : international differences in work-related values. Cross-cultural research and methodology series ; (Abridged). Beverly Hills, Calif.: Sage Publications.

Hofstede, G. (1991). Cultures and organizations : software of the mind (Rev.). London New York: McGrawHill.

Hofstede, G. (1994). Cultures and organizations, software of the mind: Intercultural cooperation and its importance for survival. Successful Strategist Series. (New). Fontana.

Hofstede, G. (2001). Culture's consequences : comparing values, behaviors, institutions, and organizations across nations (2nd ed.). Thousand Oaks, Calif.: Sage Publications.

Hofstede, G. J., \& Hofstede, G. J. (2004). Cultures and organizations: Software of the mind. The successful strategist series. (Rev. and e). London: McGraw-Hill.

House, R. J., Hanges, P. J., Javidan, M., Dorfman, P. W., \& Gupta, V. (2004). GLOBE associates. Leadership, Culture and Organizations: The GLOBE Study of 62 Nations.

House, R. J., Hanges, P. J., Ruiz-Quintanilla, S. A., Dorfman, P. W., Javidan, M., \& Dickson, M. V. (1999). Cultural influences on leadership: Project GLOBE. In Mobley. W., Gessner. J., \& V. Arnold (Eds.), Advances in Global Leadership (Vol. 1, pp. 171-233). Stamford. CT: JAI Press.

Howard, A. (1997). A reassessment of assessment centers: Challenges for the 21 st century. Journal of Social Behavior and Personality, 12, 13-52.

Imada, A. S., Van Slyke, M. D., \& Hendrick, H. W. (1985). Applications of assessment centres multinationally: The state of the art, obstacles and cross-cultural implications. Journal of Management Development, 4(4), 54-67.

International Task Force on Assessment Center Guidelines. (2009). Guidelines and Ethical Considerations for Assessment Center Operations. International Journal of Selection and Assessment, 17, 243-253.

James, K. (1993). The social context of organizational justice: Cultural, intergroup, and structural effects on justice behaviors and perceptions. In R. Cropanzano (Ed.), Justice in the workplace: Approaching fairness in human resource management (pp. 21-50). Hillsdale, NJ: Lawrence Erlbaum Associates.

Kabanoff, B. (1991). Equity, equality, power, and conflict. Academy of Management Review, 416-441.

Keles, S., \& Aycan, Z. (2011). The relationship of managerial values and assumptions with performance management in Turkey: understanding within culture variability. The International Journal of Human Resource Management, 22(15), 3080-3096.

Lanik, M., \& Gibbons, A. M. (2011). Guidelines for cross-cultural assessor training in multicultural assessment centers. The Psychologist-Manager Journal, 14(4), 221-246.

Laurent, A. (1986). The cross-cultural puzzle of international human resource management. Human Resource Management, 25, 91-102.

Lievens, F., \& Chapman, D. S. (2009). Recruitment and selection. In A. Wilkinson, T. Redman, S. Snell, \& N. Bacon (Eds.), Handbook of Human Resource Management (pp. 133-154). Sage.

Lievens, F., Chasteen, C. S., Day, E. A., \& Christiansen, N. D. (2006). Large-scale investigation of the role of trait activation theory for understanding assessment center convergent and discriminant validity. Journal of Applied Psychology, 91, 247-258.

Lievens, F., Harris, M. M., Van Keer, E., Bisqueret, C., \& Acad, M. (2003). Predicting cross-cultural training performance: The validity of personality, cognitive ability, and dimensions measured by an assessment center and a behavior description interview. Journal of Applied Psychology, 88, 476489.

Lievens, F., \& Thornton, G. C. (2005). Assessment centers: Recent developments in practices and research. In N. A. A. Evers \& O. V. (Ed.), Handbook of Selection (pp. 243-264). Madden, MA: Blackwell.

Lim, L. (2001). Work-related values of Malays and Chinese Malaysians. International Journal of Cross Cultural Management, 1(2), 209.

Lind, E. A., Tyler, T. R., \& Huo, Y. J. (1997). Procedural context and culture: Variation in the antecedents of procedural justice judgments. Journal of Personality and Social Psychology, 73(4), 767.

Love, K. G., Bishop, R. C., Heinisch, D. A., \& Montei, M. S. (1994). Selection across two cultures: Adapting the selection of American assemblers to meet Japanese job performance demands. Personnel Psychology, 47, 837-846.

Lustig, M. W., \& Koester, J. (2003). Intercultural competence: Interpersonal communication across cultures (4th ed.). Boston: Allyn and Bacon. 
MacKinnon, D. W. (1977). From selecting spies to selecting managers - The OSS Assessment Program. In J. L. Moses \& W. C. Byham (Eds.), Applying the assessment center method (pp. 3-11). New York: Pergamon Press.

McCarthy, J. M., Bauer, T. N., Truxillo, D. M., Anderson, N. R., Costa, A. C., \& Ahmed, S. M. (2017). Applicant Perspectives During Selection: A Review Addressing "So What?,"“What's New?," and "Where to Next?" Journal of Management, 43(6), 1693-1725.

Mendonca, M., \& Kanungo, R. N. (1994). Managing human resources: The issue of cultural fit. Journal of Management Inquiry, 3, 189-205.

Mendonca, M., \& Kanungo, R. N. (1996). Impact of culture on performance management in developing countries. International Journal of Manpower, 17, 65-69.

Moses, J. L., \& Byham, W. C. (1977). Applying the assessment center method. In J. L. Moses \& W. C. Byham (Eds.), Applying the assessment center method (p. xi, 310). New York: Pergamon Press.

Mueller-Hanson, R. A., Thornton, G. C., \& Rupp, D. E. (2017). Developing Organizational Simulations: A Guide for Practitioners, Students, and Researchers. Routledge.

OSS Assessment Staff. (1948). The assessment of men: Selection of personnel Officer of Stratrgic Services. New York: Johnson Reprint Corp.

Pendit, V. G. (2011). Assessment center adaptation and implementation in Indonesia. In N. Povah \& G. C. Thornton (Eds.), Assessment Centres and Global Talent Management (pp. 363-374). Surrey: Gower Publishing.

Public Service Commission of Malaysia. (2011). Public Service Commission Circular Number 1, Year 2011, Garis Panduan Permohonan Pengisian Kekosongan Jawatan. Putrajaya: Government of Malaysia.

Public Service Commission of Malaysia. (2012). Annual Report 2011. Kuala Lumpur.

Public Service Commission of Malaysia. (2013). Annual Report 2012. Kuala Lumpur.

Public Service Commission of Malaysia. (2014). Annual Report 2013. Kuala Lumpur.

Rogers, E. M., Hart, W. B., \& Miike, Y. (2002). Edward T. Hall and the history of intercultural communication: The United States and Japan. Keio Communication Review, 24(3), 3-26.

Rosner, S. R., \& Kleiner, B. H. (1998). Managing for excellence in Malaysia. Management Research News, 2l(6), 17-22.

Rupp, D. E., Hoffman, B. J., Bischof, D., Byham, W., Collins, L., Gibbons, A., ... Lanik, M. (2015). Guidelines and Ethical Considerations for Assessment Center Operations. Journal of Management, 149206314567780.

Ryan, A. M., Boyce, A. S., Ghumman, S., Jundt, D., Schmidt, G., \& Gibby, R. (2009). Going global: Cultural values and perceptions of selection procedures. Applied Psychology, 58(4), 520-556.

Salleh, L. M. (2005). High/low context communication: The Malaysian Malay style. In 70th Association for Business Communication Annual Convention. Irvine, Carlifornia.

Sanchez, J. I., \& Levine, E. L. (1999). Is job analysis dead, misunderstood, or both? New forms of work analysis and design. In A. I. Kraut \& A. K. Korman (Eds.), Evolving practices in human resource management (pp. 43-68). San Francisco, CA: Jossey-Bass.

Savvas, M., El-Kot, G., \& Sadler-Smith, E. (2001). Comparative study of cognitive styles in Egypt, Greece, Hong Kong and the UK. International Journal of Training and Development, 5, 64-73.

Schein, E. H. (1992). How can organizations learn faster?: the problem of entering the Green Room.

Schein, E. H. (2004). Organizational culture and leadership (3nd.). San Francisco, CA: Jossey-Bass.

Scott, B. A., Garza, A. S., Conlon, D. E., \& Kim, Y. J. (2014). Why do managers act fairly in the first place? A daily investigation of "hot" and "cold" motives and discretion. Academy of Management Journal, 57(6), 1571-1591.

Steiner, D. D., \& Gilliland, S. W. (2001). Procedural justice in personnel selection: International and crosscultural perspectives. International Journal of Selection and Assessment, 9(1-2), 124-137.

Thornhill, A. (1993). Management training across cultures: The challenge for trainers. Journal of European Industrial Training, 17, 43-51.

Thornton, G. C. (2011). Fifty years and counting: The ongoing reciprocal impact of science and practice of the assessment center method. In G. C. Thornton \& N. Povah (Eds.), Assessment Centres and Global Talent Management. Surrey, England: Gower Publishing.

Thornton, G. C., \& Byham, W. C. (1982). Assessment centers and managerial performance. New York: Academic Press.

Thornton, G. C., \& Gibbons, A. M. (2009). Validity of assessment centers for personnel selection. Human Resource Management Review.

Thornton, G. C., \& Povah, N. (2011). Assessment center in organizational and cultural contexts: Evidence of the versatility of a proven human resource intervention. In N. Povah \& G. C. Thornton (Eds.), Assessment Centres and Global Talent Management (pp. 471-480). Surrey, England: Gower Publishing. 
Thornton, G. C., \& Rupp, D. E. (2006). Assessment centers in human resource management. New Jersey: Lawrence Erlbaum Associates.

Thornton, G. C., Rupp, D. E., \& Hoffman, B. J. (2014). Assessment Center Perspectives for Talent Management Strategies. Routledge.

Ugwu, C. C., \& Ojeaga, O. E. D. (2016). Organizational justice and employee work engagement: A comparative study of private and public sector organization in Nigeria. Global Journal of Applied, Management and Social Sciences, 13, 78-94.

Vallance, S., \& Fellow, H. (1999). Performance appraisal in Singapore, Thailand and the Philippines: A cultural perspective. Australian Journal of Public Administration, 58, 78-95.

Wiechmann, D., Ryan, A. M., \& Hemingway, M. (2003). Designing and implementing global staffing systems: Part I - Leaders in global staffing. Human Resource Management, 42(1), 71-83.

Wright, P., Szeto, W. F., \& Cheng, L. T. W. (2002). Guanxi and professional conduct in China: a management development perspective. International Journal of Human Resource Management, 13(1), 156-182.

Zhang, Y., LePine, J. A., Buckman, B. R., \& Wei, F. (2014). It's not fair... or is it? The role of justice and leadership in explaining work stressor-job performance relationships. Academy of Management Journal, 57(3), 675-697. 